Volume 1 Issue 1 (2017) Pages 12 - 18

Jurnal Obsesi : Jurnal Pendidikan Anak Usia Dini

DOI: $10.31004 /$ obsesi.v1i1.27

\title{
Pengenalan Bahasa Arab melalui Nyanyian \\ pada Anak Usia Prasekolah di PAUD Terpadu Ihyaul Ulum Puncu Kediri Jatim
}

\author{
Khoiruddin $\bowtie$ \\ Dosen STAI Hasanuddin Pare Kediri Jatim
}

\begin{abstract}
Abstrak
Tujuan kegiatan adalah untuk memperkenalkan bahasa Arab melalui nyanyian pada anak usia dini di PAUD Terpadu Ihyaul Ulum Gadungan Kecamatan Puncu Kediri, dan mengetahui proses belajar mengajar bahasa Arab melalui nyanyian. Metode penelitian menggunakan analisis deskriptif terhadap kegiatan yang dilakukan dalam upaya peningkatan kemampuan mengenal bahasa Arab pada anak usia dini . Prosesnya kegiatan dilakukan dengan menggunakan beberapa metode seperti bernyanyi sambil bermain dan bernyanyi dengan menggunakan gerakan serta bernyanyi dengan menggunakan media pembelajaran. Kesimpulan dari kegiatan ini adalah; (1) melalui nyanyian dengan metode bermain yaitu menyanyi dengan gerakan, maka anak-anak usia pra sekolah dapat dengan mudah mengenal kosakata-kosakata bahasa Arab, (2) Anak-anak usia TK memiliki minat yang tinggi dalam mengenal bahasa Arab. Hal ini dapat dilihat dari antusias anak-anak ketika menyanyikan nyanyian-nyanyian berbahasaArab yang diajarkan, dan (3) Isi nyanyian pendek dan bahasa yang digunakan mudah sehingga siswa dengan mudah mencerna dan mengucapkan kosakata bahasa Arab
\end{abstract}

Kata kunci : bahasa Arab, Bernyanyi sambil bermain, mengajar bahasa Arab

\begin{abstract}
The purpose of the event is to introduce Arabic through singing at early childhood in Education Ihyaul Ulum Gadungan Puncu Kediri Integrated School, and know the process of learning to teach Arabic through singing. The research method used a descriptive analysis of the activities undertaken in an effort to improve the ability to recognize Arabic language in early childhood. The process is done by using several methods such as singing while playing and singing using the movement and singing using the learning media. The conclusion of this activity is; (1) through singing with the method of play is singing with the movement, then pre-school children can easily recognize the vocabulary of Arabic, (2) Kindergarten children have a high interest in knowing Arabic. This can be seen from children's enthusiasm when singing familiar Hymnic songs, and (3) The content of short songs and easy-to-use language so that students easily digest and
\end{abstract}

Keyword : Arabic language, singing with the movement, learning Arabic language

@ Jurnal Obsesi Prodi PG-PAUD FIK UPTT 2017

$\triangle$ Corresponding author :

Address : Jalan Gede II Kauman Pare Kabupaten Kediri Jatim

ISSN 2356-1327 (Media Cetak)

Email : khoiruddin1962@gmail.com ISSN 2549-8959 (Media Online) 


\section{PENDAHULUAN}

Upaya bangsa untuk meningkatkan kualitas hidup bangsa menjadi sangat strategis dan menentukan sebagai kunci sukses memasuki pasar global di abad ini. Pendidikan adalah salah satu upaya bangsa dalam meningkatkan kualitas hidup manusia. Pendidikan anak sejak dini dipandang sebagai bagian utama peningkatan kualitas mutu hidup manusia, karena anak adalah kelompok strategis keberlanjutan bangsa. (Ni Made Oktiana Dewi, I Nyoman Wirya, 2014)

Pendidikan merupakan usaha sadar menyiapkan peserta didik untuk mencerdaskan kehidupan bangsa serta mewariskan nilai-nilai luhur budaya bangsa sehingga membentuk manusia yang berkualitas. Pendidikan bertujuan agar budaya yang merupakan nilai nilai luhur budaya bangsa dapat diwariskan dan dimiliki oleh generasi muda. Agar tidak ketinggalan zaman, senantiasa relevan dan signifikan dengan tuntutan hidup.

Diantara sekian banyak budaya yang perlu diwariskan kepada generasi muda adalah bahasa, karena bahasa marupakan alat yang sangat penting untuk berkomunikasi. Setiap negara mempunyai bahasa nasional sendirisendiri. Biasanya bahasa itu tersusun dari bahasa-bahasa daerah yang ada, sehingga memungkinkan adanya penggunaan dua bahasa atau lebih dalam berkomunikasi.

Bahasa merupakan suatu bentuk menyampaikan pesan terhadapsegala sesuatu yang diinginkan. Bagi seseorang, bahasa sangatlah penting sehingga harus ditanamkan sejak usia dini agar anak memiliki kemampuan berbahasa yang baik ketika dewasa nanti. Oleh karena itu, taman kanak-kanak atau pendidikan prasekolah merupakan wahana yang sangat penting dalam mengembangkan bahasa anak. (Iin Priyanti, 2015)

Masyarakat Indonesia mengenal berbagai macam bahasa ketika masih kanakkanak dikenal bahasa ibu yaitu bahasa daerah, setelah masuk sekolah menengah diajarkan bahasa-bahasa asing pada sekolah-sekolah. Dan salah satu bahasa Asing yang diajarkan di sekolah-sekolah tersebut adalah bahasa Arab, terutama di sekolah-sekolah Islam dan pondok pesantren.
Bahasa Arab sebagai bahasa yang hidup, baik berbentuk klasik atau kuno maupun yang modern mempunyai kegunaan yang penting dalam agama, ilmu pengetahuan dalam pembinaan dan pembentukan kebudayaan nasional, bahkan hubungan internasional. Mengingat pentingnya bahasa Arab, maka perlu ditanamkan kepada generasi-generasi muda dari sejak kecil. Masa kecil adalah masa yang ajaib, ini dapat dilihat kala anak lahir. Ia tidak mempunyai apapun. Aktivitasnya kebanyakan hanya tidur, makan, dan menangis. Tetapi tiga tahun kemudian, kita bisa melihatnya telah dapat melakukan berbagai aktivitas dan telah menjadi manusia sesungguhnya. Kita juga menyaksikan berbagai perubahan drastis pada usia prasekolah dalam sekejap mata. Dalam tiga tahun anak telah berkembang dari bayi yang masih merangkak dan tidak dapat berbicara sama sekali menjadi manusia sesungguhnya yang bisa berbicara dan bisa berjalan (Borden, 2001)

Pada masa inilah bimbingan orangtua, guru dan lingkungan sekitar mempunyai peranan yang sangat urgen. Kebanyakkan padamasa ini anak sebagian besar waktunya berada di lingkungan sekolah. Karena itulah makapengaruh yang paling mendominasi adalah pengaruh lingkungan sekolah. Di sini orangtua sangat berpengaruh terhadap kemajuan bahasa anak, ibu dan juga orang lain harusmemberi contoh kepada anak dengan bahasa yang lengkap dan baik. Bahasa yang seringdidengar oleh anak akan ditirunya. Hendaknya selalu berhati-hati dengan pemakaian bahasa.

Supaya anak lekas dapat berbicara dengan dengan baik dan lengkap. Pendidik (ibu, ayah,saudara-saudara yang lain) harus sering mengajak anak berbicara (Barnadib, 1982). Namun ada hal penting yang harus diperhatikan dalam proses belajar mengajartermasuk belajar bahasa adalah anak belajar tidak disertai stres. Awalnya, lakukan cara-carabelajar dengan fleksibel atau melalui permainan agar menarik bagi anak. Dan salah satu teknik yang dapat dilakukan untuk mengajarkan bahasa termasuk mengenalkan bahasa asing adalah melalui nyanyian, karena melalui kegiatan ini anak tidak dituntut untukberpikir. Terkadang, bagi anak-anak yang usianya masih sangat muda, 
perhatiannya seringkali beralih. Namun, meski anak belum intensif memperhatikan nyanyian tersebut, mereka dapat mempelajarinya dengan mendengar.

Berdasarkan wacana diatas, maka penulis tertarik untuk memperkenalkan salah satubahasa asing yakni bahasa Arab untuk anakanak melaui nyanyian terutama pada anak usia prasekolah di PAUD Terpadu Ihyaul Ulum Gadungan Puncu Kediri. Dipilihnya PAUD Terpadu Ihyaul Ulum ini adalah karena di PAUD ini telah diajarkan membaca huruf-huruf hijaiyyah -huruf Arab-, sehingga dalam pelaksanaan,anak-anak dapat melafalkan lagulagu (nyanyian) bahasa Arab yang diajarkan.

Berdasarkan analisis situasi diatas, maka perumusan masalah yang diangkat dalam pengabdian ini adalah sebagai berikut : (1) Bagaimana pengenalan bahasa Arab melalui nyanyian pada anak usia prasekolah di PAUD Terpadu Ihyaul Ulum Gadungan kecamatan Puncu? (2) Bagaimana proses belajar mengajar bahasaArab melalui nyanyian pada anak usia prasekolah di PAUD Terpadu Ihyaul Ulum Gadungan kecamatan Puncu?

Adapun tujuan kegiatan pengabdian iniadalah : (1) Memperkenalkan bahasa Arab melalui nyanyian pada anak usia prasekolah di PAUD Terpadu Ihyaul Ulum Gadungan kecamatan Puncu, (2) Mengetahui proses belajar mengajar bahasaArab melalui nyanyian pada anak usia prasekolah di PAUD Terpadu Ihyaul Ulum Gadungan Puncu Kediri.

Menurut Biechler dan Snowman yang dikutip (Patmonodewo \& Soemiarti, 2003), anak prasekolah adalah mereka yang berusia antara 3-6 tahun. Mereka biasanya mengikuti program prasekolah dan kinderganten.

Sedangkan di Indonesia, umumnya mereka mengikuti program tempat penitipan anak (3 bulan 5 tahun) dan bermain (usia 3 tahun) sedangkan pada usia 4-6 tahun biasanyamereka mengikuti program Taman Kanakkanak. Menurut teori Erikson yang membicarakan kepribadian seorang dengantitik berat pada perkembangan psikososial tahapan 0-1 tahun, berada pada tahapan oralsensorik dengan krisis emosi antara "trust versus ministrust", tahapan 3-6 tahun, merekadalam tahapan dengan krisis ,autonony versusshame and doubt" (2-3 tahun), initiative versusguilt, (4-5 tahun) tahap usia 6-11 tahun mengalami krisis „industry versus inferiority" (Patmonodewo \& Soemiarti, 2003).

Kesadaran akan semakin pentingnya peranan bahasa asing sebagai media komunikasi dewasa ini dipandang sangat perlu. Sehingga pengenalan bahasa asing dalam hal ini bahasa Arab sebaiknya diberikan kepada anak sejak usia dini (prasekolah) tanpa adanya unsur paksaan. Alasannya adalah anak usia prasekolah yaitu berdasarkan hasil risetotak mutakhir, perkembangan otak 95 persenterjadi pada usia dini, yaitu di bawah umur 7 tahun. Dan masa 3 tahun pertama adalah saat membangun pondasi struktur otak yang akan berdampak permanen. Jaringan komunikasi antar sel terbentuk karena adanya rangsangan (stimulasi) dari luar. Semakin kaya pengalaman dan rangsangan, semakin kompleks jaringan sel otak. Ketika anak tertarik pada sesuatu dan mempelajarinya, semakin kompleks jaringan sel otak (Sudono, 2000). Oleh karena itu, pola pengasuhan yang penuh kasing sayang sangat diperlukan. Dan, menciptakan lingkungan yang bebas dari ketakutan dan beban. Dengan demikian diharapkan anak akan tumbuh dalam suasana yang kreatif, lepas dan tanpa beban.

Anak sebagai sosok manusia kecil yang sedang menjalani proses tumbuh dan berkembang yang sangat pesat. Anak usia dini adalah sosok individu yang berada pada rentang usia 0-6 tahun yang mana pada masa ini sering disebut sebagai masa Golden Age. Pada masa ini stimulasi yang diberikan oleh orang dewasa memegang peranan yang sangat penting dalam mengembangkan aspek perkembangan anak. Mengingat, perkembangan otak anak usia dini ini mengalami percepatan hingga mencapai $80 \%$ dari keseluruhan otak orang dewasa. Hal tersebut mengindikasikan bahwa seluruh potensi anak sudah mulai terbentuk pada usia tersebut. Atas dasar itulah maka anak usia dini memerlukan stimulasi dari sejak dini demi mengoptimalkan potensi yang mereka miliki. Stimulasi ini tentunya dapat diperoleh melalui pendidikan. Salah satu stimulasi bagi anak usia dini dapat dilakukan melalui Pendidikan Anak Usia Dini atau sering disebut dengan PAUD.(Nopiyani \& Natalina, 2016) 
Senada dengan hal diatas, (Fauziddin, 2017) Dalam mengembangkan potensi pada diri anak hendaknya dimulai sejak dini, hal ini dapatditempuh melalui pendidikan pra sekolah, yaitu taman kanak-kanak atau lebih dikenal dengan TK/RA. Ini merupakan salah satu bentuk pendidikan pra sekolah yang dapat mempersiapkan proses pembelajaran lebih lanjut atau jenjang pendidikan yang lebih tinggi. Sehingga hal ini tidak lepas dari adanya seorang guru.

\section{Strategi Pembelajaran Bahasa Arab Untuk Anak Usia Dini}

Untuk memilih dan menentukan strategi pembelajaran bahasa Arab untuk anak, guru hendaknya terlebih dahulu memahami dengan baik prinsip-prinsip pembelajaran bahasa Arab untuk anak dan karakteristik anak yang akan diajar. Karakteristik anak tersebut antara lain bahwa anak (a) masih belajar dan senangberbicara tentang lingkungan mereka, (b) senang bermain, (c) senang mempraktikkan sesuatu yang baru diketahui/ dipelajarinya, (d) cenderung suka bertanya, (e) cenderung suka mendapatkan penghargaan, dan (f) cenderung mau melakukan sesuatu karena dorongan dari luar.

Berdasarkan karakteristik tersebut guru dapat memilih strategi pembelajaran bahasa Arab untuk anak yang sesuai. Salah satu karakteristik anak adalah bahwa pengetahuan mereka masih sangat terbatas pada lingkungan hidup mereka sehari-hari.

Berdasarkan hal tersebut, maka materi pelajaran sebaiknya dipilihkan hal-hal yang terkait dengan lingkungan mereka. Misalnya tentang diri mereka sendiri, orang tua (bapak/ibu), saudara kandung, rumah danisinya, binatang piaraan, mainan, lingkungan sekolah, dan teman bermain.

Bermain merupakan sesuatu yang menyenangkan. Hampir tidak ada permainan yang membuat anak tidak senang. Dalam bermain anak melakukan berbagai kegiatan yang berguna untuk mengembangkan dirinya. Anak mengamati, mengukur, membandingkan bereksplorasi, meneliti, dan masih banyak lagi yang dapat dilakukan anak. Situasi seperti ini sering dilakukan tanpa disadari bahwa anak telah melatih dirinya dalam beberapa kemampuan tertentu sehingga anak memiliki kemampuan baru. (Ni Kd Adi Nopilayanti1, I Km. Ngr. Wiyasa2, 2016). Dari pernyataan diatas dapat dipahami bahwa bermain merupakan metode yang sangat sesuai dengan karakteristik anak usia dini.

Dalam memilih metode atau teknik pembelajaran bahasa Arab untuk anak, guru juga perlu melihat salah satu karakteristik yang menonjol pada anak, yaitu bahwa mereka senang bermain. Melihat karakteristik seperti itu, maka metode yang relevan untuk pembelajaran bahasa Arab untuk anak adalah metode bermain dengan berbagai tekniknya. Dan salah satu teknik yang sesuai adalah melalui nyanyian, karena melalui nyanyian anak akan belajar sekaligus bermain melalui lagu-lagu yang didendangkan/ dinyanyikannya.

Nyanyian merujuk kepada aktivitas membunyikan suara dalam bentuk tertentu yang bertujuan menghasilkan nada dan melodiyang disenangi. Ia merupakan salah satu aktiviti manusia yang bertujuan untuk mengembirakan hati. Nyanyian boleh dilakukan dengan bantuan alat musik atau hanya dengan secara bertepuk tangan dan sebagainya. Nyanyian memerlukan daya kreativitas manusia dan dianggap sebagai salah satu cabang seni.

Adapun tujuan pemanfaatan lagu dalam pembelajaran bahasa Arab antara lain untuk : (a) menumbuhkan sensitifitas anak terhadap bunyi, irama, dan nada dalam bahasa Arab; (b) melatih pengucapan ungkapan sederhana dalam bahasa Arab; (c) melatih penggunaan kosakata bahasa Arab yang ada dalam lagu; (d) mengembangkan permainan dengan bunyibunyi dalam bahasa Arab; (e) mengembangkan permainan dengan peragaan lagu yang dihapalkan; (f) memperkenalkan ejaan, kalimat berita, kalimat tanya dan perintah.

Disamping itu, lagu dapat dimanfaatkan untuk tujuan : (a) membuat kaitan antara kegiatan dan benda/obyek melalui syair lagu,(b) meresapkan bunyi-bunyi bahasa Arab, (c)mengembangkan kepekaan ritme, dan (d) menghapal kosakata.Hal-hal yang perlu diperhatikan dalam memilih lagu untuk 
pembelajaran bahasa Arab bagi anak usia prasekolah antara lain :

1. Syair atau kata-kata dalam lagu hendaknya jelas.

2. Bahasa yang digunakan dalam lagu tersebut tidak terlalu sulit

3. Tema lagu dipilih yang sesuai dengan dunia anak

4. Lagu tidak terlalu panjang (panjang pendek lagu disesuaikan dengan tingkatan atau kelas anak)

5. Lagu diupayakan memiliki keterkaitan dengan materi yang diajarkan.

\section{METODE PENELITIAN}

Metode penelitian menggunakan analisis deskriptif terhadap kegiatan yang dilakukan dalam upaya peningkatan kemampuan mengenal bahasa Arab pada anak usia dini. Untuk mencapai tujuan yang diharapkan dalam kegiatan pengabdian kepada masyarakat ini maka bentuk kegiatan yang akan dilakukan adalah pengajaran yaitu pengenalan bahasa Arab melalui nyanyian pada anak usia prasekolah. Dalam prosesnya kegiatan akan dilakukan dengan menggunakan beberapa metode seperti bernyanyi sambil bermain dan bernyanyi dengan menggunakan gerakan serta bernyanyi dengan menggunakan media pembelajaran.

Pada proses penyampaian materi teori beberapa metode seperti menyanyi dan demontrasi akan digunakan secara bervariasi. Sedangkan pada materi praktek proses pengenalan bahasa asing melalui nyanyian. Untuk mengetahui pencapaian tujuan dan keberhasilan kegiatan pengabdian kepada masyarakat ini maka akan digunakan kriteria keberhasilan sebagai berikut:

1. Anak-anak usia prasekolah PAUD Terpadu Ihyaul Ulum mampu melafalkan lagu-lagu bahasa Arab denganbaik

2. Anak-anak usia prasekolah PAUD Terpadu Ihyaul Ulum mampu menyanyikan lagu-lagu bahasa Arab dengan baik dan kegembiraan

3. Guru dan anak-anak usia prasekolah PAUD Terpadu Ihyaul Ulum dapat mengikuti proses belajar mengajar bahasa Arab melalui nyanyian dengan baik

\section{HASIL DAN PEMBAHASAN \\ Pelaksanaan Pengabdian}

Kegiatan pengabdian pengenalan bahasaArab melalui nyanyian ini dilaksanakan di PAUD Terpadu Ihyaul Ulum Gadungan Puncu Kediri. Kegiatan ini dilaksanakan selama empat kali pertemuan yakni satu minggu sekali selama satu bulan. Jumlah peserta yang dilibatkan dalam kegiatan pengabdian kepada masyarakat ini adalahguru-guru TK Terpadu Ihyaul Ulum yang berjumlah 7 orang, dan anakanak TK Terpadu Ihyaul Ulum kelas B tahunajaran 2009/2010 yang berjumlah 25 orang.

Bentuk kegiatan yang akan dilakukan adalah pengajaran yaitu pengenalan bahasa Arab melalui nyanyian pada anak usiaprasekolah. Prosesnya kegiatan dilakukan dengan menggunakan beberapa metode seperti bernyanyi sambil bermain dan bernyanyi dengan menggunakan gerakan serta bernyanyi dengan menggunakan media pembelajaran.

\section{Pertemuan Pertama}

Pertemuan pertama pengenalan bahasa Arab melalui nyanyian pada anak usia prasekolah di PAUD Terpadu Ihyaul Ulum ini dilaksanakan pada hari Rabu tanggal 2 Januari 2016. Nyanyian yang disampaikan pada pertemuan pertama ini adalah nyanyian sebagai berikut :

\section{(Aku Sayang Ibu)}

Satu-satu, aku sayang ibu

Dua-dua, juga sayang ayah

Tiga-tiga, sayang adek kakak

Satu dua tiga, sayang semuanya

Nyanyian bahasa Arab yang berjudul ini merupakan nyanyian yang disadur dari nyanyian anak-anak Indonesia berbahasa Indonesia yang berjudul "AkuSayang Ibu". Melalui nyanyian ini anak diperkenalkan dan mengetahui kosa kata bahasa Arab yang berhubungan dengan angka atau bilangan seperti Uwla yang berarti satu, tsaniyah yang berarti dua, dan tsalisah yangberarti tiga. Melalui nyanyian ini guru dananak juga mengetahui kosakata yang berhubungan dengan anggota keluarga, sepertikosakata umi yang berarti ibu, dan abi yang berarti ayah.

Lagunya menjadi seperti ini: 


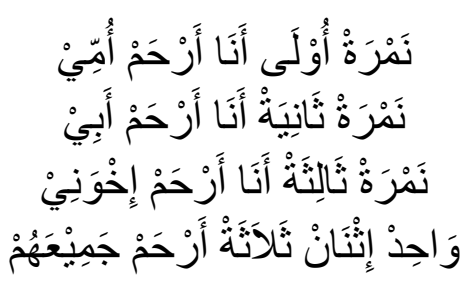

Namroh Uulaa Anaa Arham Ummii

Namroh Tsaaniyah Anaa Arham Abii

Namroh Tsaalitsah Anaa Arham Ikhwanii

Waahid Itsnan Tsalaatsah Arham Jamii'ahum

Nyanyian yang berjudul ini mengajarkan tentang akhlak atau moral yang hendaknya dimiliki anak-anak yakni akhlak atau moral untuk saling menyayangi. Nyanyian ini disampaikan dengan gerakan badan dan tangan. Anak-anak meniru pula menyanyikannya dengan gerakan dantangan.

Pada pertemuan pertama ini guru dan anak-anak PAUD Terpadu Ihyaul Ulum mengikuti kegiatan pengenalan bahasa Arab dengan semangat karena mendapatkan pelajaran yang belum mereka pelajari sebelumnya.

\section{Pertemuan Kedua}

Pertemuan kedua pengenalan bahasaArab melalui nyanyian pada anak usia prasekolah di PAUD Terpadu Ihyaul Ulum ini dilaksanakan pada hari Rabu tanggal 3 Janurai 2016. Pada pertemuan kedua ini, disamping mengulang nyanyian yang berjudul yang sudah diperkenalkan pada pertemuan pertama untuk mengingat kembalidan memperlancar nyanyian tersebut, juga diperkenalkan nyanyian yang berjudul sebagaiberikut :

(Disadur dari lagu anak-anak "Dua Mata Saya")

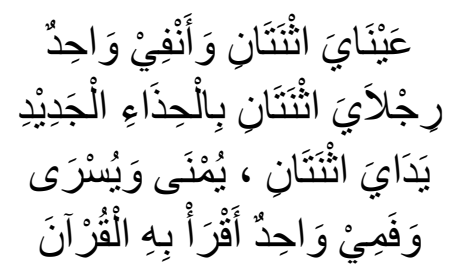

'Ainaayats Nataani Wa Anfii Waahidun Rijlaayats Nataani Bil Hidzaa-Il Jadiid Yadaayats Nataani, Yumnaa Wa Yusroo

Wa Famii Waahidun Aqro' Bihil Qur'aan

Nyanyian bahasa Arab yang berjudul ini merupakan nyanyian yang disadur dari nyanyian anak-anak Indonesia berbahasa Indonesia yang berjudul "Dua Mata Saya ". Melalui nyanyian ini anak diperkenalkan dan mengetahui kosakata bahasa Arab yang berhubungan dengan anggota tubuh, seperti kosa kata ainun yang berarti mata, anfun yang berarti hidung, dan rijlun yang berarti kaki.

Nyanyian ini disampaikan dengan gerakan badan dan anggota badan. Sambil bernyanyi guru dan anak-anak menunjuk anggota badan yang sesuai dengan kosa kata bahasa Arab yang dinyanyikan.

Pertemuan Ketiga

Pertemuan ketiga pengenalan bahasaArab melalui nyanyian pada anak usia prasekolah di PAUD Terpadu Ihyaul Ulum ini dilaksanakan pada hari Rabu tanggal 4 Januari 2016.

Pada pertemuan ketiga ini, nyanyian bahasa Arab yang diperkenalkan merupakan lanjutan dari nyanyian bahasa Arab yang berjudul yang sebagian diajarkan pada pertemuan kedua. Adapun lanjutan nyanyian bahasa Arab tersebut sebagai berikut :

(Disadur dari lagu anak-anak "Dua Mata Saya")

\section{Dua tangan saya \\ Yang kiri dan kanan \\ Satu mulut saya \\ Untuk membaca al-Qur'an}

Nyanyian ini juga disampaikan dengan gerakan badan dan anggota badan. Sambil bernyanyi guru dan anak-anak menunjuk anggota badan yang sesuai dengan kosa kata bahasa Arab yang dinyanyikan. Kosa kata bahasa Arab yang diperkenalkan pada pertemuan ini adalah kosakata yang juga berhubungan dengan anggota tubuh, yakni yadun yang berarti tangan, dan famun yang berarti mulut.

\section{Pertemuan Keempat}

Pertemuan keempat pengenalan bahasa Arab melalui nyanyian pada anak usia prasekolah di PAUD Terpadu Ihyaul Ulum ini dilaksanakan pada hari Jum'at tangga 6 Januari 2016. Pada pertemuan keempatini anak-anak tidak diperkenalkan nyanyianbahasa Arab yang baru, hanya mengulang kembali lagu-lagu yang sudah diajarkan pada pertemuan pertama, kedua dan ketiga. Hal ini dimaksudkan sebagai evaluasi hasil terhadap kegiatan yang sudah dilaksanakan. Untuk memotivasi anak-anak diberikan penghargaan terhadap anak-anak 
yang dapat menyanyikan lagu-lagu berbahasa Arab yang sudah diajarkan. Hasilnya $75 \%$ yakni 20 orang anak dapat menyanyikan lagulagu berbahasa Arab dengan baik disertai dengan gerakan yang menunjukkan pada arti kosakata yang sudah diketahui anak-anak.

Pada pertemuan keempat ini, juga diperkenalkan 20 (dua puluh) nyanyian anakanak berbahasa Arab kepada guru-guru PAUD Terpadu Ihyaul Ulum dengan mediadan buku panduannya. Hal ini dimaksudkan agar guruguru tersebut dapat meneruskan kegiatan pengenalan bahasa Arab melalui nyanyian pada anak usia pra sekolah ini pada waktu yang akan datang.

\section{SIMPULAN}

Berdasarkan hasil dan pembahasan dari pelaksanaan pengabdian kepada masyarakat, maka diperoleh simpulan sebagai berikut:

1. Melalui nyanyian yang disampaikan dengan metode bermain yaitu menyanyi dengan gerakan, maka anak-anak usia prasekolah dapat dengan mudah mengenalkosatakosakata bahasa Arab

2. Anak-anak usia pra sekolah memiliki minat yang tinggi dalam mengenal bahasaArab. Hal ini dapat dilihat dari antusiasanak-anak ketika menyanyikan nyanyian-nyanyian berbahasa Arab yang diajarkan.

3. Isi nyanyian pendek dan bahasa mudah sehingga siswa dengan mudah mencerna dan mengucapkan kosa kata bahasa Arab

Setelah pelaksanaan Pengabdian kepada Masyarakat, maka disarankan kepada guru atau orang tua yang memiliki anak usia prasekolah dalam mengenalkan bahasa asing sebaiknya menggunakan metode yang menyenangkan seperti melalui nyanyian.

\section{UCAPAN TERIMA KASIH}

Ucapan terima kasih disampaikan kepada Kepala Sekolah dan tenaga pengajar di PAUD Ihyaul Ulum Gadungan Kecamatan Puncu Kabupaten Kediri yang telah banyak membantu dalam proses penelitian penerapan metode bernyanyi dalam mengenalkan bahasa Arab pada anak usia dini, semoga bermanfaat apa yang sudah dilakukan.

\section{DAFTAR PUSTAKA}

Barnadib. (1982). Filsafat pendidikan : tinjauan mengenai beberapa aspek dan proses pendidikan. Yogyakarta: Studing.

Borden, M. E. (2001). Smart Start: TheParents "Complete Guide ToPrescool Education (Terjemah). Ary.

Fauziddin, M. (2017). Penerapan Belajar Melalui Bermain Balok Unit untuk Meningkatkan Kreativitas Anak Usia Dini. Curricula, 1(3). https://doi.org/http://dx.doi.org/10.22216/ JCC.2016.v2i3.1277

Iin Priyanti, N. S. (2015). Optimalisasi kecerdasan emosi melalui musik feeling band pada anak usia dini. Care, 3(1), 2033.

Ni Kd Adi Nopilayanti1, I Km. Ngr. Wiyasa2, I. G. A. O. N. (2016). Mengembangkan Motorik Kasar Anak Kelompok A TK Raisma Putra Denpasar. Jurnal PGPAUD UNDIKSA, 4(2).

Ni Made Oktiana Dewi, I Nyoman Wirya, N. M. A. (2014). Penerapan Metode Bermain Berbantuan Media Balok Cruissenare untuk Meningkatkan Perkembangan Kognitif. E-Journal PG PAUD Universitas Pendidikan Ganesha, 2(1).

Nopiyani, S., \& Natalina, D. (2016). The Increase of Early Chilhood Pre-Reading Ability Through Edutainment Method, 19.

Patmonodewo \& Soemiarti. (2003). Pendidikan Anak Prasekolah. Jakarta: Rineka Cipta.

Sudono, A. (2000). Sumber belajar dan Alat Permainan (untuk Anak UsiaDini). Bandung: Grasindo. 